\title{
Gastro-oesophageal candidiasis: diagnosis by brush cytology
}

\author{
JENNIFER A YOUNG, E ELIAS \\ From the Departments of Pathology and Medicine, Queen Elizabeth Hospital and University of Birmingham, \\ Birmingham
}

SUMMARY The diagnosis of gastro-oesophageal candidiasis by brush cytology was studied in two groups. In eight immunosuppressed patients clinically suspected to have candidiasis, fungal infection was confirmed on six occasions, and a diagnosis of herpetic oesophagitis was established in the other two cases. Among 482 gastric and oesophageal brushings clinically unsuspected candidiasis was found on a further 12 occasions. Coexisting abnormalities including carcinoma, lymphoma, and postradiation oesophagitis were also identified by brushing. Of the 18 patients with cytologically confirmed candidiasis, endoscopic biopsies were available in 13 , but histological diagnosis of fungal infection was possible in only two $(15 \cdot 5 \%)$.

Candida is the most common cause of fungal infection in immunosuppressed and debilitated patients and the incidence is increasing. ${ }^{2}$ Endoscopic biopsy is usually advocated as the potential tool for diagnosis. ${ }^{2}$ Biopsy, however, samples only a limited area and carries a risk of haemorrhage. Previous studies have confirmed the efficiency of cytology for the rapid diagnosis of opportunistic fungal infection ${ }^{34}$ and gastric and oesophageal disease. ${ }^{56}$ The present report describes our experience with gastrooesophageal brush cytology for the diagnosis of candidiasis of the upper digestive tract.

\section{Patients and methods}

Material from 20 cases, obtained from two groups, was available for study. Group 1 comprised eight patients who were immunosuppressed after renal transplant or as the result of acute myeloid leukaemia, Hodgkin's disease, or rheumatoid arthritis and were clinically suspected to have gastrooesophageal candidiasis. The renal transplant recipients were taking cyclosporin $\mathrm{A}$ or azathioprine and prednisolone and the patient with rheumatoid arthritis was also receiving steroids. The patient with Hodgkin's disease had undergone mantle irradiation, and the woman with acute myeloid leukaemia had a history of carcinoma of the breast. Group 2 comprised 12 further patients found during review of 482 cases in whom candidiasis had not been clini-

Accepted for publication 5 December 1984 cally suspected but from whom gastric or oesophageal brushings had been taken. The group 2 cases were not taking immunosuppressive drugs. One 19 year old woman was pregnant and suffering from hyperemesis gravidarum and one patient was examined twice. In 13 of the 20 patients from the two groups biopsies had also been collected. Among the total 490 cases none was found with Candida sp present in endoscopic biopsies but absent from brushings.

The brushings in both groups 1 and 2 were obtained with standard cytology brushes, which were passed and withdrawn in protective plastic sheaths. Four smears were prepared from each brush. In group 1 these were stained by the Papanicolaou and Grocott methenamine silver techniques. In group 2 , in most instances, only Papanicolaou stained material was used. In six patients from group 1 and seven from group 2, one to four biopsies were taken with standard endoscopic forceps after the brushing. Culture was not attempted in any of the cases. The ages of the patients and sites of specimen collection are shown in Tables 1 and 2.

\section{Results}

The incidence of candidiasis found on review of the 490 brushings was $3.7 \%$ ( 18 cases), and in 12 patients $(2.5 \%)$ the condition was unsuspected before endoscopy. The results of brushing and biopsy for groups 1 and 2 are given in Tables 1 and 
Table 1 Diagnosis of candidiasis and associated conditions by endoscopic brushing and biopsy in immunosuppressed patients

\begin{tabular}{|c|c|c|c|c|c|c|}
\hline $\begin{array}{l}\text { Patient } \\
\text { no }\end{array}$ & Age & Sex & $\begin{array}{l}\text { Clinical } \\
\text { condition }\end{array}$ & $\begin{array}{l}\text { Site of } \\
\text { examination }\end{array}$ & $\begin{array}{l}\text { Cytological } \\
\text { diagnosis }\end{array}$ & $\begin{array}{l}\text { Histological } \\
\text { diagnosis }\end{array}$ \\
\hline $\begin{array}{l}1 \\
2 \\
3 \\
4\end{array}$ & $\begin{array}{l}42 \\
37 \\
74 \\
42\end{array}$ & $\begin{array}{l}\mathbf{M} \\
\mathbf{M} \\
\mathbf{F} \\
\mathbf{M}\end{array}$ & $\begin{array}{l}\text { RT } \\
\text { RT } \\
\text { AML } \\
\text { HD }\end{array}$ & $\begin{array}{l}\text { Oesophagus } \\
\text { Oesophagus } \\
\text { Oesophagus } \\
\text { Oesophagus }\end{array}$ & $\begin{array}{l}\text { Candidiasis } \\
\text { Candidiasis } \\
\text { Candidiasis } \\
\text { Candidiasis } \\
\text { Postradiation changes }\end{array}$ & $\begin{array}{l}\text { Non-diagnostic } \\
\text { Non-diagnostic } \\
\text { Candidiasis } \\
\text { Non-diagnostic }\end{array}$ \\
\hline $\begin{array}{l}5 \\
6 \\
7 \\
8\end{array}$ & $\begin{array}{l}64 \\
49 \\
28 \\
32\end{array}$ & $\begin{array}{l}\mathbf{M} \\
\mathbf{M} \\
\mathbf{M} \\
\mathbf{M}\end{array}$ & $\begin{array}{l}\text { RA } \\
\text { RT } \\
\text { RT } \\
\text { RT }\end{array}$ & $\begin{array}{l}\text { Oesophagus } \\
\text { Oesophagus } \\
\text { Oesophagus } \\
\text { Stomach }\end{array}$ & $\begin{array}{l}\text { Candidiasis } \\
\text { HSV } \\
\text { HSV } \\
\text { NHL, candidiasis }\end{array}$ & $\begin{array}{l}\text { Not done } \\
\text { Not done } \\
\text { HSV } \\
\text { NHL, candidiasis }\end{array}$ \\
\hline
\end{tabular}

RT = renal transplant; $\mathrm{HD}=$ Hodgkin's disease; $\mathrm{HSV}=$ Herpes simplex virus; $\mathrm{AML}=$ acute myeloid leukaemia; $\mathrm{RA}=$ rheumatoid arthritis; NHL = non-Hodgkin's lymphoma.

Table 2 Diagnosis of candidiasis and associated conditions by endoscopic brushing and biopsy in debilitated patients

\begin{tabular}{|c|c|c|c|c|c|}
\hline $\begin{array}{l}\text { Patient } \\
\text { no }\end{array}$ & Age & Sex & $\begin{array}{l}\text { Site of } \\
\text { examination }\end{array}$ & $\begin{array}{l}\text { Cytological } \\
\text { diagnosis }\end{array}$ & $\begin{array}{l}\text { Histological } \\
\text { diagnosis }\end{array}$ \\
\hline $\begin{array}{r}9 \\
10 \\
11 \\
12 \\
13 \\
14 \\
15 \\
16\end{array}$ & $\begin{array}{l}76 \\
81 \\
79 \\
19 \\
65 \\
67 \\
57 \\
65\end{array}$ & $\begin{array}{l}\mathbf{M} \\
\mathbf{M} \\
\mathbf{M} \\
\mathrm{F} \\
\mathrm{M} \\
\mathrm{F} \\
\mathbf{F} \\
\mathbf{M}\end{array}$ & $\begin{array}{l}\text { Oesophagus } \\
\text { Oesophagus } \\
\text { Oesophagus } \\
\text { Oesophagus } \\
\text { Oesophagus } \\
\text { Oesophagus } \\
\text { Oesophagus } \\
\text { Oesophagus }\end{array}$ & \multirow{3}{*}{$\begin{array}{l}\text { Candidiasis } \\
\text { Candidiasis } \\
\text { Candidiasis } \\
\text { Candidiasis } \\
\text { Candidiasis } \\
\text { Candidiasis } \\
\text { Candidiasis } \\
\text { Adenocarcinoma } \\
\text { Candidiasis } \\
\text { Candidiasis } \\
\text { Candidiasis } \\
\text { Adenocarcinoma } \\
\text { Candidiasis } \\
\text { (i) Adenocarcinoma } \\
\text { (ii) Adenocarcinoma } \\
\text { Candidiasis }\end{array}$} & $\begin{array}{l}\text { Non-diagnostic } \\
\text { Non-diagnostic } \\
\text { Not done } \\
\text { Not done } \\
\text { Non-diagnostic } \\
\text { Not done } \\
\text { Not done } \\
\text { Adenocarcinoma }\end{array}$ \\
\hline $\begin{array}{l}17 \\
18 \\
19\end{array}$ & $\begin{array}{l}81 \\
51 \\
72\end{array}$ & $\begin{array}{l}\mathrm{M} \\
\mathrm{F} \\
\mathrm{M}\end{array}$ & $\begin{array}{l}\text { Stomach } \\
\text { Stomach } \\
\text { Stomach }\end{array}$ & & $\begin{array}{l}\text { Not done } \\
\text { Non-diagnostic } \\
\text { Adenocarcinoma }\end{array}$ \\
\hline 20 & 74 & $\mathbf{M}$ & Stomach & & $\begin{array}{l}\text { Non-diagnostic } \\
\text { Adenocarcinoma }\end{array}$ \\
\hline
\end{tabular}

2. In group 1 pseudohyphae and blastospores of Candida sp were seen in five of the seven oesophageal brushings and in the one gastric brushing. Owing to immunosuppression the background of the smears was free of inflammatory cells and the fungal elements were closely intermingled with viable squamous or columnar epithelial cells in all instances (Figure). In three of the six cases biopsied the sections did not contain Candida sp. In patients 6 and 7 oesophageal brushing showed no evidence of candidiasis, but the squamous cells displayed clear morphological stigmata of herpes simplex virus infection. Two patients in group 1 had associated disorders identifiable in the cytological specimens. In patient 4 , who was receiving mantle irradiation for Hodgkin's disease, bizarre squamous cells containing enlarged or multiple nuclei consistent with postradiation changes were seen in the brushings but were not present in the biopsies. Patient 8 , a renal transplant recipient, had non-Hodgkin's lymphoma of the stomach. The tumour was also present in the biopsies.

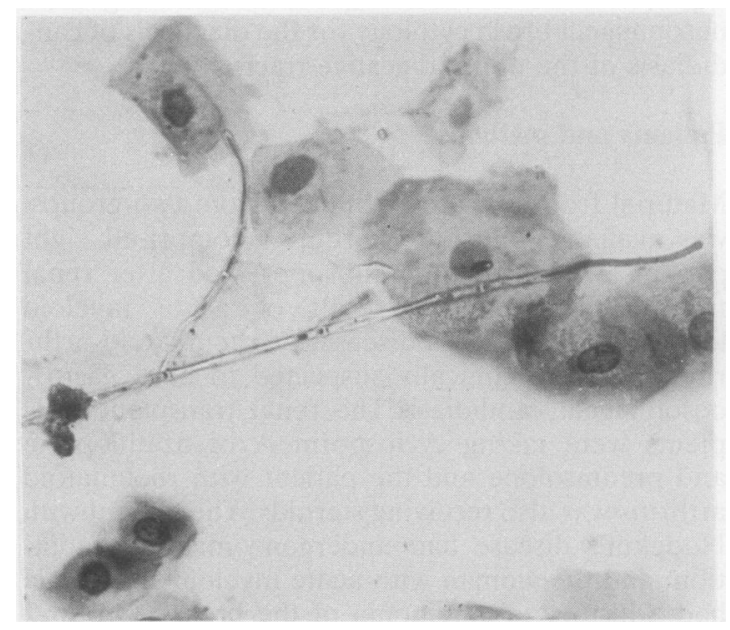

Candida sp mixed with well preserved squamous cells from the oesophagus. The background is free of inflammatory cells because of immunosuppressive therapy. Papanicolaou. $\times 580$. 
The 12 patients in group 2 were identified from the cytology files. The brushings all contained Candida sp closely intermingled with groups of squamous or columnar epithelial cells. In seven of these cases biopsies were collected but none showed evidence of candidiasis. Special stains for the identification of fungi were not, however, carried out on all the biopsies at the time of reporting. The brushings from three patients also contained malignant epithelial cells. One man (patient 20) was examined twice. At the first endoscopy the diagnosis of adenocarcinoma was made solely on the brushings. Malignancy was confirmed by both brushing and biopsy at the second endoscopy.

\section{Discussion}

Candida sp can produce lesions at any of multiple levels in the alimentary tract, but the distal oesophagus and stomach are the most common sites of infection.' The diagnosis of gastrointestinal candidiasis is important because the condition may seriously influence prognosis as it can cause haemorrhage or dysphagia and associated cachexia. ${ }^{7}$ In immunosuppressed and agranulocytic patients, lethal disseminated candidiasis may arise by a number of mechanisms, but the most prevalent route is spread of alimentary tract infection. ${ }^{2}$ In immunocompromised subjects such as the eight in group 1, although clinical suspicion may be high, candidiasis must be distinguished from other possible gastro-oesophageal disorders including herpetic oesophagitis, drug and radiation effects, and malignant infiltration. More than one of these conditions may coexist.

Gastro-oesophageal candidiasis, however, also occurs in patients without a history of immunosuppression, such as those in group 2. Symptoms referable to the fungal infection are uncommon ${ }^{4}$ and the condition is therefore often clinically unsuspected until diagnosed endoscopically. ${ }^{89}$ Candidiasis is not infrequently found as a complication of other local disease $^{y 10}$ and is associated with a high postoperative mortality." Katzenstein and Maksem," for example, found a mortality of $38 \%$ among patients undergoing surgery for benign peptic ulcer complicated by gastric candidiasis, compared with $8.3 \%$ for cases without evidence of fungal infection.

Symptoms and signs of both localised and disseminated candidiasis are often nondescript and oesophageal infection in particular may be totally asymptomatic. ${ }^{2}$ Radiology is often unhelpful ${ }^{7}$ and culture and serological tests are of limited value, especially in immunosuppressed patients. ${ }^{2}$ The identification of white plaques in the oesophagus at endoscopy is also not diagnostic as these may occur with reflux oesophagitis. ${ }^{9}{ }^{12}$ Endoscopic biopsy is therefore generally advocated as the method of choice for the verification of gastro-oesophageal infection. ${ }^{2}$

The findings in the present study, however, show that the sensitivity of brushing is much higher than that of endoscopic biopsy for the diagnosis of gastro-oesophageal candidiasis. Candida was seen in only two $(15.5 \%)$ biopsies compared with 13 $(100 \%)$ brushings in the 13 patients from whom both types of specimens were collected. In addition, when the files were searched, no cases were identified with diagnostic biopsies and nondiagnostic brushings. This is in keeping with the previous observations of Kodsi $e t a l^{8}$ that biopsy was diagnostic in only $10 \%$ of cases of oesophageal candidiasis and that of Minoli et $a^{10}$ that brush cytology was more sensitive than biopsy for the diagnosis of gastric "thrush." In addition to the advantage of wider tissue sampling by brushing in comparison with biopsy, Kodsi $e t a l^{8}$ also considered that fungal elements were readily lost from biopsies during their immersion in fixative.

Pseudohyphae and blastospores of Candida sp can be recognised without difficulty in smears stained by the Papanicolaou method. Grocott methenamine silver staining is a useful confirmatory technique and if cellular material is limited can be successfully carried out on slides previously stained by the Papanicolaou method. Speciation of fungi is seldom possible by morphological examination alone and while Candida albicans is the species seen most often in this country, it cannot be distinguished from, for example, $C$ stellatoidea or $C$ tropicalis in cytological preparations. This, however, does not affect patient management. A more important consideration is the occurrence of saphrophytic Candida $\mathrm{sp}$ in the mouth and pharynx which may be swallowed in saliva. The use of a sheathed brush and optimum preparation of the patient before endoscopy is mandatory. On examination of brushings it is essential that only fungal elements closely intermingled with viable epithelial cells are considered diagnostic of gastro-oesophageal candidiasis. Fungus mixed solely with degenerate squamous debris may be of oral origin and should not be considered as evidence of infection.

Gastro-oesophageal candidiasis often coexists with other localised abnormalities, most commonly gastric ulcer or oesophageal or gastric carcinoma. One patient in this series (patient 18) had a gastric ulcer. The presence of ulceration cannot be ascertained from brushing; only the associated inflammatory and regenerative changes are seen. Cytology, however, is a highly sensitive method for the diagnosis of malignancy.5 6 There were four 
malignant tumours in this series, all of which were diagnosed by brushing. Biopsy gave a false negative result at the first endoscopy in one of these patients (patient 20). Cytopathologists are familiar with postradiation morphological alterations in squamous cells from examination of cervical smears ${ }^{13}$ and can therefore readily discern similar appearances when they are seen in squamous cells of oesophageal origin. Evidence of postradiation change in addition to candidiasis was seen in brushings from one of the immunosuppressed patients (patient 4) and neither condition was recognised in the biopsy material. Similarly the cytological stigmata of herpes simplex virus infection, multiple closely moulded nuclei, ground glass nuclei, and eosinophilic intranuclear inclusions may be quickly identified in oesophageal brushings (patients 6 and 7) and the distinction made from oesophageal candidiasis.

As in the previous reports on pulmonary infiltrates, ${ }^{34}$ this study shows the efficiency of cytology as an investigative technique for the diagnosis of opportunistic fungal and viral infections and malignant disease in immunosuppressed and debilitated patients. In the immunosuppressed patients, in whom fungal infection was suspected, and in the debilitated patients, in whom it was not, brush cytology was a more sensitive technique than endoscopic biopsy for the diagnosis of gastro-oesophageal candidiasis and also facilitated accurate identification of coexisting abnormalities.

We thank the many clinicians who referred patients or participated in this series including Dr D Adu, Dr J Michael, Mr J Fielding, and Mr J Temple. We are also indebted to the staff of the Department of Pathology who reported the histology; Dr Lesley A Smallman, who examined the brushings from patient 8; Mr William P Cuthbertson for technical assistance; and Miss Angela Wright for typing the manuscript.

\section{References}

' Myerowitz RL, Pazin GP, Allen CM. Disseminated candidiasis: changes in incidence, underlying disease and pathology. Am J Clin Pathol 1977;68:29-38.

${ }^{2}$ Myerowitz RL. The pathology of opportunistic infections. New York: Raven Press, 1983:95.

${ }^{3}$ Hopkin LM, Turney JH, Young JA, Adu D, Michael J. Rapid diagnosis of obscure pneumonia in immunosuppressed renal patients by cytology of alveolar lavage fluid. Lancet 1983;ii:299-301.

4 Young JA, Hopkin JM, Cuthbertson WP. Pulmonary infiltrates in immunocompromised patients: diagnosis by cytological examination of bronchoalveolar lavage fluid. J Clin Pathol 1984;37:390-7.

${ }^{5}$ Young JA, Hughes HE. Three year trial of endoscopic cytology of the stomach and duodenum. Gut 1980;21:241-6.

- Young JA, Hughes HE, Lee FD. Evaluation of endoscopic brush and biopsy touch smear cytology and biopsy histology in the diagnosis of carcinoma of the lower oesophagus and cardia. $J$ Clin Pathol 1980;33:811-4.

' Eras P, Goldstein MJ, Sherlock P. Candida infection of the gastrointestinal tract. Medicine 1972;51:367-79.

${ }^{8}$ Kodsi BE, Wickremesinghe PC, Kozinn PJ, Iswara K, Goldberg PJ. Candida oesophagitis-a prospective study of 27 cases. Gastroenterology 1976;71:715-9.

' Scott BB, Jenkins D. Gastro-oesophageal candidiasis. Gut 1982;23:137-9.

${ }^{10}$ Minoli G, Terruzzi V, Butti G, Frigerio G, Rossini A. Gastric candidiasis: an endoscopic and histological study in 26 patients. Gastrointest Endosc 1982;28:59-61.

" Katzenstein AA, Maksem J. Candidal infection of gastric ulcers. Am J Clin Pathol 1978;71:137-41.

${ }_{12}$ Thompson H. Pathology of reflux oesophagitis. In: Atkinson M, ed. Clinics in gastroenterology. London: Saunders, 1976:143-54.

${ }^{13}$ Takahashi M. Color atlas of cancer cytology. 2nd ed. Tokyo: Igaku-Shoin, 1981:83-93.

${ }^{14}$ Young JA. Endoscopic cytology of the gastrointestinal tract. Dublin, Ireland: University of Dublin, 1982. MD thesis.

Requests for reprints to: Dr Jennifer A Young, Department of Pathology, The Medical School, University of Birmingham, Birmingham B15 2TJ, England. 